\title{
Quo Vadis Ecumenical Hermeneutics: Challenges of the New Ecumenical Situation*
}

\author{
ZDENKO Š ŠIRKA ${ }^{* *}$
}

This article deals with the development of hermeneutics in the dialogue between confessions within the ecumenical movement, from its beginnings in 1927 until the current time. As an overview of historical circumstances, it critically presents the main document of ecumenical hermeneutics, including its contemporary tendencies and challenges. Special attention is given to the various models of ecumenical hermeneutics, the influence of philosophical hermeneutics, as well the role of hermeneutical questions in the contemporary ecumenical dialogue.

Keywords: hermeneutics, ecumenical dialogue, tradition, Church

This article deals with the relationship between hermeneutics and ecumenical dialogue. This connection is not so obvious to any of the partners in the dialogue: neither to those who deal with hermeneutics, nor those who are involved in the ecumenical movement; thus, is the goal of the following lines to fill this gap.

Since 1998 and publication of $A$ Treasure in Earthen Vessels document, it is actually legitimate to talk about the ecumenical hermeneutics, as this document brings an answer to the recent shift of paradigms about what the ecumenism is. Therefore, I will start by sketching this new ecumenical circumstance, then present the discussions and the most important milestones, as well as explain the role of the document Baptism, Eucharist, and Ministry. From there, I will critically analyse the hermeneutical Treasure in Earthen Vessels document and finish by showing connections between philosophical and ecumenical hermeneutics.

\section{Limits of Contextualisation}

At the end of the $20^{\text {th }}$ century a major change in ecumenism occurred and so it is correct to talk of a new ecumenical situation. This shift is a result of the clash between traditional and contextual theologies. Konrad Raiser compares this situation to the experience of the Early Church, which had to

\footnotetext{
* This work has been supported by Charles University Research Centre program No. 204052.

* Zdenko Š Širka, Ph.D., Protestant Theological Faculty of Charles University, Ecumenical Institute, researcher. Černá 9, PO Box 529, 11555 Praha 1, Czech Republic, zdenko.sirka@ gmail.com.
} 
cope with the rapid growth of its membership. In an effort to maintain unity while at the same preserving diversity, the Early Church created several criteria that enabled this, such as the biblical canon, the rule of faith, the church structure and leadership. ${ }^{1}$

The modern ecumenical movement is confronted by a similar situation, when Christian communities are positioned all over the world, on all continents, in all cultures and civilisations, and this raises many problems and challenges. One of them is the need to have a common framework, a platform that would enable adequate communication between traditional and appropriated/contextualized forms of Christianity.

An example of this emerging theological self-confidence was also visible at the Seventh General Assembly of the World Council of Churches in Canberra, Australia in 1991. I am referring to the criticism against Chung Hyun Kyung of South Korea, addressed by Orthodox participants regarding her lecture on the Holy Spirit, which she introduced with dance and music. In the discussion, she was accused of 'syncretism'.

In the ecumenical dialogue, the term syncretism is commonly used in the context of 'translating' the Christian message into different cultural environments, more specifically to describe a situation in which this translation has gone too far and has even compromised the Christian faith. ${ }^{3}$ Chung Hyun Kyung's lecture was the result of translating the perception of the Holy Spirit into the cultural context of South Korea, especially in the situation of women, and the audience criticized her approach for going too far. ${ }^{4}$ Her story is used only illustratively to point at the lack of hermeneutic criteria in ecumenical dialogue as a problem.

\footnotetext{
1 See: Konrad Raiser, "Beyond Tradition and Context: In Search of an Ecumenical Framework", in: International Review of Mission 80 (1991), p. 351-352.

2 See more on this in: K. Raiser, "Beyond Tradition and Context", p. 347-349. See also: Athanasios Basdekis, "Canberra und die Orthodoxen. Anfragen und die Forderungen an den ÖRK im Anschluß an den 7. Vollversammlung”, in: Ökumenische Rundschau 40 (1991), p. 356-374, or Lawrence E. Adams, "The WCC at Canberra: Which Spirit?”, in: First Things 1 (1991), p. 30-37.

3 In this meaning it is used in the document Guidelines on Dialogue with People of Living Faiths and Ideologies (1979), see: https://www.oikoumene.org/en/resources/documents/ wcc-programmes/interreligious-dialogue-and-cooperation/interreligious-trust-and-respect/ guidelines-on-dialogue-with-people-of-living-faiths-and-ideologies, viewed 21. 10. 2019.

4 "We must guard against a tendency to substitute a 'private' spirit, the spirit of the world or other spirits for the Holy Spirit who proceeds from the Father and rests in the Son." See: Michael Kinnamon (ed.), Signs of the Spirit: Official Report of the Seventh Assembly of the World Council of Churches, Geneva, World Council of Churches 1991, p. 281; for reactions of the Orthodox participants see: p. 279-282.
} 
The problem was that the Orthodox participants and Chung Hyun Kyung did not use the same language: while the lecture was given in the framework of contextual hermeneutics, its opponents used the hermeneutics of tradition, which is based on the tradition of the apostolic faith as the normative criterion of ecumenical conversation. ${ }^{5}$ The report from the General Assembly described the situation very clearly:

Some lack of coherence is natural in a fellowship like the WCC.

Nevertheless, the quest for a coherent theology is crucially important and must remain a priority. In this context, it is important to bring contextual theologies into dialogue with "classical" theologies in order to develop an ecumenical way of practicing theology. ${ }^{6}$

Does this mean, then, that Scripture has no central message, and that all means of appropriating the Gospel are legitimate? All of them?

In current times the interpretation of Scripture and possible consensus on its meaning among the various ecclesial communities has become almost impossible, mainly due to the fragmentation of interpretative methods and a variety of approaches. ${ }^{7}$ At present, the preferred emphasis on the perspective of the reader has not simplified the situation, but made it even more complicated, as the diversity of the readers has been manifested, and their different contexts gained a very important role.

I have in mind primarily the voices from Africa, Asia and Latin America. ${ }^{8}$ In the face of this situation, the key question arises: what kind of

5 See also an article from a similar context: Ahram Kang, "Ecumenical Hermeneutics through a Study of Missiological Typologies", in: International Review of Mission 104 (2015), p. 345-360.

${ }^{6}$ M. Kinnamon (ed.), Signs of the Spirit, p. 185. See also the report of the meeting in Chambésy (Switzerland) from September 1991 "Inter-Orthodox consultation after the Canberra assembly", online here: https:/www.oikoumene.org/en/resources/documents/ wcc-programmes/ecumenical-movement-in-the-21st-century/member-churches/special-commission-on-participation-of-orthodox-churches/sub-committee-ii-style-ethos-ofour-life-together/inter-orthodox-consultation-after-the-canberra-assembly, viewed 21. 10. 2019. In the same spirit talks also former General Secretary of the WCC Konrad Raiser in his article, where he focuses on the impact of globalization and religious plurality on WCC. See: K. Raiser, "Opening space for a culture of dialogue and solidarity", in: International Review of Mission 88 (1999), p. 197-206.

7 Nice overview of these methods gives Old Testament professor and former dean of the Protestant Theological Faculty at the University of Heidelberg, Manfred Oeming in his book: Manfred Oeming, Contemporary Biblical Hermeneutics: An Introduction, London, Routledge 2006.

8 See on this especially: Pavol Bargár, "The Reformation from the Perspective of World Christianity”, in: Acta Universitatis Carolinae Theologica 8 (2018), p. 67-89. Bargár starts with an example of Tanzanian Lutheran bishop Josiah Mutabuzi Isaya Kibira to argue that if Christianity is to be regarded as a truly world religion, Christians must pay serious attention to the ways in which the Christian legacy has taken roots and found contextualized 
hermeneutics should be used to support the efforts of those who want to achieve visible unity of the Church? Discussion about an ecumenical style of theology that would respond to this situation became the programmatic content of ecumenical meetings in the 1990s under the heading of "ecumenical hermeneutics". ' In particular, the Commission on Faith and Order of the World Council of Churches placed strong emphasis on the search for a common framework of ecumenical communication and mutual recognition.

What is ecumenical hermeneutics? Until the end of the $19^{\text {th }}$ century, hermeneutics was a scientific discipline that provided the rules of correct interpretation in any situation when the proper meaning was unclear. As hermeneutica sacra, it has developed since the Renaissance, along with hermeneutics profana and iuris. Biblical exegesis is connected to this understanding of hermeneutics, which by definition seeks to express the true meaning of Scripture in biblical terms. But hermeneutics is far more than an interpretation of texts. According to Czech theologian Petr Pokorný, hermeneutics is not simply a theory of interpretation, but a theory of understanding in general. ${ }^{10}$ Ecumenical hermeneutics does not focus only on texts, but also on living symbols, practices and rituals.

In the ecumenical movement, ecumenical hermeneutics is an attempt to discover the reasons for the apparent lack of consensus visible in the different ways of reading Scripture, and in the difficulty of finding mutual understanding among Christians. At the same time, it is an attempt to create a common framework in which churches can communicate, mu-

expressions around the world, particularly in the global South. If Christians from the North Atlantic fail to acknowledge and take this fact seriously in their theological reflection, it will be to the detriment of their own spirituality and faith tradition.

9 Although the project of ecumenical hermeneutics formally emerged in 1993, voices about the need for ecumenical hermeneutics were heard before. Cardinal Joseph Ratzinger already in 1983 talked about the Hermeneutik der Einheit, see: Joseph Ratzinger, "Probleme und Hoffnungen des anglikanisch-katholischen Dialogs", in: Internationale katholische Zeitschrift 12 (1983), p. 244-259. The term "ecumenical hermeneutics" was used in 1990 by Anton Houtepen to refer to hermeneutics shared by all churches, i.e. hermeneutics of coherence, which in his view is based on the ecumenical quadriga (ökumenisches Viereck): res gesta as a reminder of the history of Israel and the story of Jesus, allegoria as the narrative presence of a community of assembled believers, sensus moralis as a practice of following and serving the world in different ways, anagogia as a challenge to every man who is called to seek the kingdom of God and fight evil. See: Anton Houtepen, "Ökumenische Hermeneutik: Auf der Suche nach Kriterien der Kohärenz im Christentum”, in: Ökumenische Rundschau 39 (3/1990), p. 279-296. See also: A. Houtepen, "Ecumenism and Hermeneutics: Diversity, Dissemination, Coherence", in: A. Houtepen et al. (eds.), Ecumenism and Hermeneutics, Utrecht, Interuniversitair Instituut voor Missiologie en Oecumenica 1995, p. 3-19.

10 Petr Pokorný, Hermeneutics as a Theory of Understanding, Grand Rapids, Eerdmans 2011, p. 2. 
tually recognize each other and where the unity of the Church on earth will be visible. ${ }^{11}$

Before reflecting on the current state of ecumenical hermeneutics and its challenges, let me briefly present what proceeded to what we now call ecumenical hermeneutics. ${ }^{12}$

\section{From Oxford to Lima through Montreal}

From the very beginning of the ecumenical movement, the question of interpretation of Scripture has been in the centre of the ecumenical dialogues, although the very concept of hermeneutic unity had not yet been created. It was assumed that, if properly interpreted, one Gospel would unite the Church. That is why the Gospel was understood as "the message of the Church to the world" 13 at the First World Conference on Faith and Order in 1927 in Lausanne, Switzerland. This self-confidence was based on trust in the unity of the biblical message and above all, on trust in the biblical methods.

The Second World Conference on Faith and Order in Edinburgh, Scotland (1937) explicitly expressed this confidence in scientific exegesis, by conveying the expectation that even when A Treasure of the Church is in the "earthen vessels," science still can provide "the right interpretation." 14

11 Although the term ecumenical hermeneutics was introduced almost 20 years ago and has been discussed for half a century at various places, it is astonishing that authoritative works in general hermeneutics (authors such as Anthony Thiselton, Werner Jeanrond, Jens Zimmermann, John Barton) do not mention ecumenical hermeneutics at all and they are silent about development and observations from ecumenical circles. "It is as if the ecclesial and ecumenical work on hermeneutics does not exist," observes Dirkie Smit in "Ecumenical Hermeneutics? Historical Benchmarks and Current Challenges of a Concept", in: A. Frochtling, Being (the Church) beyond the South-North-Divide: Identities, Otherness and Embodied Hermeneutics, Münster, LIT 2003, p. 24.

12 Speaking of a Protestant contribution to the debate, important names are Ingolf Dalferth, Dietrich Ritschl, Ulrich Körtner, Ulrich Kühn, Lukas Vischer. On the Catholic side are Harald Wagner, Wolfgang Thönissen, Tim Lindfeld, Gregor Maria Hoff and Peter Neuner. See the overview of ecumenical hermeneutics personalities in: Michael Weinrich, "Ist der Weg das Ziel? Zur aktuallen Debatte um die ökumenische Hermeneutik", in: Theologische Literaturzeitung 136 (1/2011), p. 831-847. For circumstances of origin and overview see also: Peter-Ben Smit, "Canonical Criticism: On the Road Towards Ecumenical Hermeneutics", in: Peter-Ben Smit, From Canonical Criticism to Ecumenical Exegesis? A Study in Biblical Hermeneutics, Leiden, Brill 2015, p. 139-172; Simone Sinn, "Hermeneutics and Ecclesiology", in: Gerard Mannion, Mudge S. Lewis (eds.), The Routledge Companion to the Christian Church, New York, Routledge 2008, p. 576-596; Rudolf von Sinner, Reden vom dreieinigen Gott in Brasilien und Indien. Grundzüge einer ökumenischen Hermeneutik im Dialog mit Leonardo Boff und Raimon Panikkar, Tübingen, Mohr Siebeck 2003, p. 9-53.

13 Lukas Vischer (ed.), A Documentary History of the Faith and Order Movement: 19271963, St. Louis, Bethany Press 1963, p. 29.

${ }^{14}$ L. Vischer (ed.), A Documentary History, p. 44. 
In the aftermath of World War II, people involved in the ecumenical movement shared the belief that the ethical and political legacy of Scripture was important for the world, at least as a solution for preventing further wars, and therefore this issue was discussed at the First Assembly of the World Council of Churches (WCC) in Amsterdam, Holland in 1948. The question of correct interpretation also appeared in many bilateral and multilateral debates between churches. ${ }^{15}$

Only one year after the First Assembly, this conviction culminated in the Guiding Principles for the Interpretation of the Bible $e^{16}$ document, as prepared at the meeting at Wadham College, Oxford in 1949. The participants at this meeting sought to answer the question of how Scripture as the Word of God speaks to the affairs of the world. Yet optimism from Wadham waned quickly, as it turned out that the question of interpretation was much more complex than had been previously thought. Thus, the distinction between the Biblical world and the world in which the reader lives today must be acknowledged in the ecumenical movement, especially in the application of acquired knowledge and interpretations. ${ }^{17}$

This was necessary due to the increased awareness of the importance of the diversity of traditions, which was fully reflected at the Third Assembly of the World Council to the Church in New Delhi, India (1961), especially through the involvement of Eastern European Orthodox Churches. This process culminated at the Fourth World Conference on Faith and Order in Montreal, Canada (1963), which is considered by many to be a historical landmark in the development of ecumenical hermeneutics ${ }^{18}$ and a key breakthrough. ${ }^{19}$

The Montreal Conference produced a report that included (in Part Two, Sections 38-73) a document called Scripture, Tradition and traditions ${ }^{20}$,

15 For an overview of development in different traditions see: Michael G. Cartwright, "Hermeneutics", in: Nicholas Lossky et al. (eds.), The Dictionary of the Ecumenical Movement, Geneva, WCC Publications 2002, p. 513-519; also: Ellen Flesseman-van Leer, The Bible: Its Authority and Interpretation in the Ecumenical Movement, Geneva, WCC Publications 1980.

16 Published in: E. Flesseman-van Leer, The Bible, p. 13-17.

17 See: M. Cartwright, "Hermeneutics", p. 513.

18 See: D. Smit, "Ecumenical Hermeneutics?”, p. 26.

19 See: A. Houtepen, "Hermeneutics and Ecumenism: The Art of Understanding a Communicative God”, in: Peter Bouteneff, Dagmar Heller (eds.), Interpreting Together: Essays in Hermeneutics, Geneva, WCC Publications 2001, p. 8.

20 Published in: Patrick C. Rodger, Lukas Vischer (eds.), The Fourth World Conference on Faith and Order, Montreal 1963, New York, Association Press 1964, p. 50-61. For an appropriate interpretation of Montreal see: Martin Cressey, "Scripture, Tradition and traditions”, in: P. Bouteneff, D. Heller (eds.), Interpreting Together, p. 92-97; or Robert A. Nelson, "Scripture, Tradition and traditions", in: The Ecumenical Review 16 (2/1964), p. 158-163. 
which planned to solve all obstacles in the dialogue between the confessions. The document dealt with three different, but interconnected sections, titled: "Scripture, Tradition and traditions", "The unity of Tradition and the diversity of traditions", and finally "The Christian Tradition and cultural diversity".

Due to lack of time ${ }^{21}$ however, only the first part on Tradition was presented and discussed in the plenary; the second and third parts having to wait for several decades until they received attention. The breakthrough occurred mainly in the relationship between Scripture and Tradition, when the document "clearly under the influence of the Orthodox presence"22 states:

In our report we have distinguished between a number of different meanings of the word tradition. We speak of the Tradition (with a capital T), tradition (with a small $\mathrm{t}$ ) and traditions. By the Tradition is meant the Gospel itself, transmitted from generation to generation in and by the Church, Christ himself present in the life of the Church. By tradition is meant the traditionary process. The term traditions is used in two senses, to indicate both the diversity of forms of expression and also what we call confessional traditions, for instance the Lutheran tradition or the Reformed tradition. In the latter part of our report the word appears in a further sense, when we speak of cultural traditions. ${ }^{23}$

This is probably the most cited part from this document and represents an attempt to take a step forward in the controversial question between two approaches concerning the role of Scripture in the teaching and life of the Church. The first emphasizes sola scriptura, and the second insists on the balance between Scripture and tradition. The Montreal document does not see Scripture and Tradition as two separate entities, but rather regards Scripture as the internal norm of Tradition, and Tradition as the context of reading the Scripture.

Tradition (with a capital T) is therefore identified with the Gospel and not with particular confessions or cultural traditions. Therefore, another key passage states that we all live in the same Tradition (paradosis) that stems from the Old Testament. It is a tradition of the Gospel transmitted from one generation to another in the Church by the power of the Holy Spirit and confirmed by sacraments, preaching and mission. ${ }^{24}$ The main implication of the Montreal Document for ecumenical hermeneutics is the discovery that

${ }^{21}$ M. Cressey, "Scripture, Tradition and traditions", $\$ 41$.

22 D. Smit, "Ecumenical Hermeneutics?", p. 27.

23 M. Cressey, "Scripture, Tradition and traditions", $\$ 39$.

24 Ibidem, $\$ 45$. 
Tradition is not static but dynamic, that it always changes, and changes in various ways. It is something that is not given, it is not possible to own it, but it exists as a continuing sequence of events, as a living Tradition, and consists of a whole mosaic of activities, from preaching and ministering to sacraments, through missions and testimonies, to teaching theology.

This perception was influenced by Orthodox participants who shared their attitude to Tradition as a mystery that cannot be bound by definition. ${ }^{25}$ The significance of the document is also that the Protestant party suppressed their suspicion about the concept of tradition and acknowledged the Orthodox arguments that Scripture originated in an already existing Tradition and that the continuing Tradition creates the context for the interpretation of Scripture. The Protestant party in the draft of the document even suggested using the phrase: "Thus we can say that we exist as Christians sola traditione, by tradition alone", which, after all, was not used in the final version due the objections of Ernst Kässemann and Max Thurian. ${ }^{26}$

However, this view of mediating the Gospel in the Church with the help of the Holy Spirit failed to solve the hermeneutical problem of the relationship between Scripture and the authoritarian Church tradition, nor the relationship between Tradition and traditions. It also failed to solve the tensions between different ecclesiastical traditions in terms of preaching, teaching, holiness or Christian life. Montreal achieved nothing more than to state what are the three factors of the transmission process: original events and testimony, Scripture itself, and sermons and teachings. The question also remains whether the document takes sufficient account of the possibility that authentic traditions are a set of diverse responses to Christ's message.

During the same period as the Conference in Montreal (1963), the Second Vatican Council came up with the Dogmatic Constitution on Divine Revelation (Dei Verbum) document, which is important for our debate especially because the final published text of the constitution effectively aban-

25 These are attitudes influenced by the theology of John Meyendorff and George Florovsky. See: M. Cressey, "Scripture, Tradition and traditions”, p. 93-95. In his contribution Nicholas Lossky (Nicholas Lossky, "Tradition Revisited", in: P. Bouteneff, D. Heller [eds.], Interpreting Together, p. 98-101) explains that the distinction between tradition (lower case letter) and tradition (upper case letter) in Orthodoxy was a major issue for Russian emigrants after 1917, who came from a situation where it was assumed that Orthodoxy could exist only within culture. But in emigration they realized that Orthodoxy was not tied to a particular culture. So, what is the true nature of Orthodoxy? This situation was solved by Sergei Bulgakov when he wrote in his famous book about Orthodoxy: "Orthodoxy is the Church of Christ on earth. The Church of Christ is not an institution; it is a new life with Christ and in Christ, guided by the Holy Spirit." Sergei Bulgakov, The Orthodox Church, London, Centenary Press 1935, p. 1.

26 See more in: P. Rodger, L. Vischer (eds.), The Fourth World Conference, p. 24-25. 
doned the so-called two-source theory (Scripture and Tradition), as amended in the text:

Hence there exists a close connection and communication between sacred tradition and Sacred Scripture. For both of them, flowing from the same divine wellspring, in a certain way merge into a unity and tend toward the same end. For Sacred Scripture is the word of God inasmuch as it is consigned to writing under the inspiration of the divine Spirit, while sacred tradition takes the word of God entrusted by Christ the Lord and the Holy Spirit to the Apostles, and hands it on to their successors in its full purity, so that led by the light of the Spirit of truth, they may in proclaiming it preserve this word of God faithfully, explain it, and make it more widely known. Consequently it is not from Sacred Scripture alone that the Church draws her certainty about everything which has been revealed. Therefore, both sacred tradition and Sacred Scripture are to be accepted and venerated with the same sense of loyalty and reverence. ${ }^{27}$

If the Montreal document uses the term 'Tradition' under the influence of Orthodox participants, Vatican II prefers to use the term 'sacred Tradition' to describe the transmission of the Gospel by institutional means. In this way, the seventh article of Dei Verbum solved the problem arising from the confrontation between the Reformation emphasis on sola scriptura and the anti-Reformation theory of two sources (Scripture and Tradition). ${ }^{28}$ Even so, it showed the need for criteria that would distinguish between authentic tradition (linked to scripture) and an inauthentic tradition. ${ }^{29}$

Hence, Dei Verbum and the Montreal document both perceive Revelation primarily as an event and history of salvation, from the history of Israel, through the death and resurrection of Christ, to the work of the Holy Ghost. But neither of them responds to the question of hierarchia auctoritatem between the Scripture read during the liturgy and Scripture interpreted in the teachings and dogmas.

\footnotetext{
27 Dei verbum: dogmatic constitution on divine revelation, $\$ 9$. Online here http://www. vatican.va/archive/hist_councils/ii_vatican_council/documents/vat-ii_const_19651118_ dei-verbum_en.html, viewed on October 21, 2019.

28 "This sacred tradition, therefore, and Sacred Scripture of both the Old and New Testaments are like a mirror in which the pilgrim Church on earth looks at God, from whom she has received everything, until she is brought finally to see $\mathrm{Him}$ as $\mathrm{He}$ is, face to face". Dei verbum, $\$ 7$.

29 See more in: Richard E. Moss, "Beyond 'Two Source Theory' and 'Sola Scriptura': Ecumenical Perspectives on Scripture and Tradition”, in: Acta Theologica 35 (2/2015), p. 66-81.
} 
Thus, while Montreal was the beginning of a far more focused discussion on hermeneutic issues within the World Council of Churches, it offered no solution. After the Montreal conference, discussion continued on the question of whether it is possible to distinguish between one Apostolic Tradition and the diversity of traditions of interpretation, and if so, then how? Another question discussed was whether it is possible to determine the authenticity of faith in situations involving conflicting approaches and perspectives. Here one can distinguish between Protestant and Catholic development.

The Protestant party believed that the scientific exegesis can be a direction that will provide a definitive solution. The final round of their debates took place in Heidelberg (1967). The report was submitted to the Faith and Order Commission in 1967 in Bristol and is known as The Significance of the Hermeneutical Problem for the Ecumenical Movement. ${ }^{30}$ Although the participants were aware of the diversity of traditions and interpretations, their contribution was not ground-breaking, the document was not a significant milestone and their conclusions were very general and vague. ${ }^{31}$ The report focused on a variety of interpretative theories and avoided any reference to theological assumptions. At the same time, however, it raised the question of authority, since assuming that the Bible offers contradictory perspectives, emphasis must be placed on readers and interpreters who opt for one aspect only.

At the same time, a parallel process was taking place, more under the influence of Catholic and Orthodox thought. It did not seek answers to the questions via scientific exegesis, but focused on the question of authority. After several conferences the document The Authority of the Bible was prepared and presented in Leuven in 1971.32 The Leuven report, unlike the Bristol one, calls for involvement of the readers in the process of interpretation. It was suggested that the authority of the Bible should not consist in a kind of fixed solid quality, but that its authority must be experienced and proved in the impact that the biblical testimony has on human lives. While the problem itself was raised in its entirety in this report, including differences in the Bible, diversity of interpretations, the impact of the

30 Whole text published in: E. Flesseman-van Leer, The Bible, p. 31-41.

31 Interestingly, just a few years earlier in Heidelberg, publisher Mohr Siebeck refused the title of Hans-Georg Gadamer's book Outline of Philosophical Hermeneutics with a cynical commentary "Na, Hermeneutik, was ist denn das?", he wanted to say that no one knows what hermeneutics is. In the ecumenical movement, they seem to have known. See: Jean Grondin, Hans-Georg Gadamer: Eine Biographie, Tübingen, Mohr Siebeck 1999, p. 4.

32 Published in: E. Flesseman-van Leer, The Bible, p. 43-57. 
current circumstances on subsequent interpretation, etc., no solution was provided. $^{33}$

It seemed that the post-Montreal developments in the 1960s called into question the fundamental belief on which the whole ecumenical movement was based. The question has been raised if unifying expression of the message of Bible texts is possible at all, which is a crucial question.

In the Leuven report it has been recommended to study the relationship between the Old and New Testaments, and as the result the document The Significance of the Old Testament in Its Relation to the New was produced ${ }^{34}$ and adopted at the meeting in Bangalore, India in 1978. It pointed out the differences between the churches regarding their relationship to the Old Testament, as well as the differences in social, political and theological areas. ${ }^{35}$ In particular, the question of the unity of the biblical message was proven to be impossible if there are differences in relation to the Old Testament. The recommendations of this report were not a breakthrough, but merely required from churches that they should further examine whether the Old Testament receives an adequate and sufficient place in their teaching and liturgy.

The hermeneutic discussion faded into the background after 1978 because all energy was devoted to the preparation of the Baptism, the Eucharist and Ministry document, ${ }^{36}$ which presented an opportunity to apply the results of previous hermeneutic discussions. However, this document also raised other hermeneutic questions, and thus directly prepared the appropriate ground for the further development of ecumenical hermeneutics.

The document has unexpectedly become a turning point in the hermeneutic debate and is therefore referred to in this context as "applied ecumenical hermeneutics" and its preparation as an exercise of hermeneutics of the Tradition of the church. ${ }^{37}$

\section{From Lima to ecumenical hermeneutics through Santiago de Compostela}

The Baptism, Eucharist and Ministry document (1982), also referred to as the Lima Document, after it was completed, was sent to the churches worldwide along with four questions and each church was requested to answer

\footnotetext{
33 "Simple appealing to authority (...) was part of the problem, not the solution." D. Smit, "Ecumenical Hermeneutics?", p. 33.

34 Published in: E. Flesseman-van Leer, The Bible, p. 58-76.

35 Ibidem, p. 75.

36 Baptism, Eucharist and Ministry, Geneva, World Council of Churches 1982.

37 A. Houtepen, "Hermeneutics and Ecumenism", p. 12-13.
} 
them..$^{38}$ But what followed was unexpected. The exact wording of the first question was: "Commission would be pleased to know as precisely as possible the extent to which your church can recognize in this text the faith of the Church through the ages." Instead of answering this question, churches mostly pointed out where the Lima Document was wrong, and where it was not in line with what their church confesses and believes. But this was totally the opposite of what they were supposed to prepare, and this was the huge turnover in the ecumenical dialogue. This approach, I have in mind the approach of respondents, cannot be called ecumenical hermeneutics, as it is the comparative ecclesiology, i.e. the exact opposite of what the authors of the Lima Document sought to achieve. Here it became obvious that the theological reading presented in Montreal and Bangalore can no longer be taken for granted, and that churches in Africa, Asia and Latin America have difficulty entering into ecumenical dialogue, and are not in conformity with the hermeneutics and methodology which has been used so far. ${ }^{39}$

The most important finding, however, was that the main problem and cause of division no longer lies in the diversity of confessional traditions and theological teachings, as has been true for centuries. Since the responses and reactions of the churches to the Lima text were based on and influenced by their cultural, social and political contexts, it became obvious that the major diversity lies in the factors that have so far been called non-theological and considered marginal.

Anton Houtepen expresses concern that although churches were not asked to compare the Lima text with their own catechisms and theological handbooks, what they did was merely a strengthening of their own con-

38 "In support of this process of reception, the Commission would be pleased to know as precisely as possible

- the extent to which your church can recognize in this text the faith of the Church through the ages;

- the consequences your church can draw from this text for its relations and dialogues with other churches, particularly with those churches which also recognize the text as an expression of the ap ostolic faith;

- the guidance your church can take from this text for its worship, educational, ethical, and spiritual life and witness;

- the suggestions your church can make for the ongoing work of Faith and Order as it relates the material of this text on Baptism, Eucharist and Ministry to its long-range research project 'Towards the Common Expression of the Apostolic Faith Today'." See: Baptism, Eucharist and Ministry, p. viii, the questions are set out in the preface under which are signed William $\mathrm{H}$. Lazareth a Nikos Nissiotis.

39 On reactions see: World Council of Churches, Baptism, Eucharist \& Ministry 1982-1990: Report on the Process and Responses, 2nd ed., Geneva, WCC Publications 1990; and six volumes of Max Thurian (ed.), Churches Respond to BEM: Official Responses to the "Baptism, Eucharist and Ministry", Geneva, WCC Publications 1986-1988. 
fessional identity. ${ }^{40}$ This created a further hermeneutic gap between developments in traditional contexts and the challenges of a new generation of Christians seeking to inspire the creation of God's work in the hermeneutic community of the Church. ${ }^{41}$ In this way, the questions raised in the second and third parts of the Montreal document, which were initially ignored, returned into discussion after 20 years.

This showed the need for in-depth research into ecumenical methodology, as hermeneutics was seen as a framework for ecumenical methodology. In order to pursue a consensus, it seemed important to have a set of principles and guidelines for understanding and Scripture that would function together. Houtepen notes that even after thirty years of intensive dialogue, the results are not visible, and the reason might be in underestimating the differences in moral and political affairs, which seem to be even more important than differences in teaching and dogmas. He sees the current circumstance of the Christian Church and ecumenical dialogue as manoeuvring the ship between the Scylla of fundamentalism, which refers to the immutable foundation of faith and authority as the only criterion of truth, and the Charybdis of postmodernism, which denies any authority and tradition. ${ }^{42}$

Responses to the Lima text revealed "unexamined hermeneutical assumptions" 43 in ecumenical dialogue and directly caused an urgent request to produce a document on ecumenical hermeneutics. This call was made at the Fifth World Conference on Faith and Order in Santiago de Compostela, Spain (1993), which provided a reflection on the decade long debate concerning the Lima document. ${ }^{44}$

This conference was significant because it had to solve a large number of tasks that resulted from the arrival of new churches to the World Council of Churches. Between the fourth (1963, Montreal) and the fifth conference (1993, Santiago de Compostela) of the Faith and Order Commission, the situation changed markedly, especially within the World Council of Churches: the number of members had almost doubled since its beginning and included

\footnotetext{
40 A. Houtepen, "The Faith of the Church through the Ages: Christian Tradition and Postmodernist Challenges", in: Kurt Schori et al. (eds.), The Living Tradition, Utrecht, Interuniversitair Instituut voor Missiologie en Oecumenica 1995, p. 40-41.

41 See: A. Houtepen, "Hermeneutics and Ecumenism", p. 16.

42 A. Houtepen, "The Faith of the Church", p. 38. See also: P.-B. Smit, "The Meaning of 'Life': The Giving of Life as a Criterion for Ecumenical Hermeneutics", in: Journal of Ecumenical Studies 43 (3/2008), p. 320-332.

43 A Treasure in Earthen Vessels, $\$ 11$.

44 See: Thomas B. Best, Günther Gassmann (eds.), On the Way to Fuller Koinonia: Official Report of the Fifth World Conference on Faith and Order, Santiago de Compostela, Geneva, World Council of Churches 1994.
} 
virtually all Orthodox churches, together with the so-called young churches of the southern hemisphere. ${ }^{45}$ The Roman Catholic Church also became a member of the WCC in 1968. This new situation was the main force behind continuing the work on the ecumenical hermeneutics project. The aim of the meeting in Santiago de Compostela was not so much about discussion of traditional theological confessional questions, but primary focus was placed on the question of how the Gospel can be conveyed and received in "freshly evangelized areas", while still showing appropriate respect to local culture.

The plea for a study of ecumenical hermeneutics pursued three basic objectives:

- to overcome and to reconcile the criteriological differences with regard to a faithful interpretation of the one Gospel, recognizing the multiform richness and diversity of the Canon of the Scriptures, as it is read, explicated and applied in the life of the churches, but at the same time strengthening the awareness of the one Tradition within the many traditions;

- to express and communicate the one Gospel in and across various, sometimes even conflicting contexts, cultures and locations;

- to work toward mutual accountability, discernment and authoritative teaching and towards credibility in common witness before the world, and finally towards the eschatological fullness of the truth in the power of the Holy Spirit. ${ }^{46}$

This call led to three consultations: Dublin (1994), Lyon (1996), Bossey (1997) and two smaller meetings in Boston (1994) and Faverges (1998). The parts of the text were discussed at the meetings of the Committee on Faith and Order, in 1996 at the Plenary Committee meeting in Moshi, Tanzania, and at the annual meetings of the standing committees. The text was sent to various theologians from different contexts for comments and suggestions at various stages. ${ }^{47}$

45 In his memoir, Konrad Raiser offers a reflective account of ecumenical developments in this period, he shows how a new paradigm of the WCC has developed. See: Konrad Raiser, Challenge of Transformation, Geneva, World Council of Churches 2018.

46 A Treasure in Earthen Vessels, Geneva, WCC Publications 1998, \$12. Available also online: https://www.oikoumene.org/en/resources/documents/commissions/faith-and-order/iv-interpretation-the-meaning-of-our-words-and-symbols/a-treasure-in-earthen-vessels, viewed 21. 10. 2019. References in this article will refer to paragraphs in this document.

${ }^{47}$ The first consultation included an emphasis on the liturgical community as the primary hermeneutic locus, and an awareness of the eschatological dimension. Its report was presented in Aleppo in 1995 (see: Minutes of the Meeting of the Faith and Order Standing Commission, 5-12 January 1995, Aleppo, Syria, Geneva, WCC Publications 1995). It should also be noted that an unofficial report from this meeting (published in: Irénikon 67 [1994], p. 500-503) points to certain tensions in the discussion about the ecumenical hermeneutics. 
After five years of discussion, a fundamental text on ecumenical hermeneutics was completed in 1998.

\section{A Treasure in earthen vessels}

This ecumenical document is called $A$ Treasure in Earthen Vessels: An Instrument for an Ecumenical Reflection on Hermeneutics ${ }^{48}$ and, as stated in the introduction of the accompanying publication, ${ }^{49}$ it is a preliminary attempt to settle certain questions related to hermeneutics in the ecumenical movement. The document is based on the assumption that seeking unity between churches is a hermeneutical task. ${ }^{50}$ The text has three parts that respond to the three above-mentioned challenges from Santiago de Compostela. The primary purpose of this document is to formulate ecumenical hermeneutics, which is perceived here as "hermeneutics for the unity of the Church." ${ }^{1}$

However, it is not a text for experts (only), as it is primarily intended for a wide range of people:

- for groups preparing ecumenical documents and study programs,

- for ecumenical boards that work on deepening church relations,

- for local churches and priests, and

- for teachers of ecumenism.

Ecumenical hermeneutics is primarily an activity for all religious people grouped in Christian communities. ${ }^{52}$

Hermeneutics as such is defined in two ways: (i) the art of interpretation and application of texts, symbols and practices in the present and from the past, and (ii) the theory concerning the methods of such interpretation and application. ${ }^{53}$ Although theological hermeneutics mostly deals with texts transmitted and interpreted primarily in the tradition of faith, ecumenical hermeneutics is much broader and "serves the specific task of focusing on how texts, symbols and practices in the various churches may be interpreted,

\footnotetext{
48 Published as: A Treasure in Earthen Vessels. For interpretation see e.g.: Rudolf von Sinner, "Ecumenical Hermeneutics for a Plural Christianity: Reflections on Contextuality and Catholicity", in: Bangalore Theological Forum 34 (2/2002), p. 89-99, or Jeffrey Gross, "A Hermeneutics of History for an Ecumenical Future", in: One in Christ 46 (1/2012), p. 132-136.

49 P. Bouteneff, D. Heller (eds.), Interpreting Together, p. vii.

50 Konrad Raiser urged the churches to take this document very seriously, not only to provide all those involved in ecumenical dialogue with a working tool, but also to illuminate the unresolved issues of the past. See: Konrad Raiser, "The Nature and Purpose of Ecumenical Dialogue", in: The Ecumenical Review 52 (3/2000), p. 290.

51 A Treasure in Earthen Vessels, $\$ 5$.

52 Ibidem, $\$ 50$.

53 Ibidem, $\$ 5$.
} 
communicated and mutually received as the churches engage in dialogue." 54 The adjective "ecumenical" corresponds to the area where this hermeneutics is used, i.e. where a dialogue between confessions takes place.

Since the goal of dialogue is a visible unity, ecumenical hermeneutics is also called hermeneutics of coherence and hermeneutics of trust. ${ }^{55}$ Being aware of the temporal nature of the interpretation, it is also a hermeneutics of suspicion. ${ }^{56}$ It is clear that ecumenical hermeneutics does not contain a romantic notion of understanding and consensus without conflict and criticism. The Church is considered to be a platform where this interpretation is carried out, on all levels, including local churches. Therefore, the Church is identified as a hermeneutic community.

The aim of ecumenical hermeneutics is:

(i) to strive at greater coherence in the interpretation of the faith and in the community of all believers as their voices unite in common praise of God,

(ii) to make possible a mutually recognizable (re)appropriation of the sources of the Christian faith, and

(iii) to prepare ways of common confession and prayer in spirit and truth. ${ }^{57}$

The ecumenical method, which is based on this concept of ecumenical hermeneutics, is then formed by discussing the three areas (tradition, context and reception).

In my opinion, this text is, by its content, an essential document that for several reasons goes beyond the field of ecumenical dialogue. ${ }^{58}$ The first reason is that hermeneutics of suspicion is also taken into account, which shows how often the reading of Scripture has been affected, damaged and misshapen by human interests and by perspectives of power.

The document acknowledges that its interpretations always come from specific historical-cultural circumstances of those who interpret, and it is therefore necessary for churches to examine their own initial interpretative positions, the influence of power structures on interpretation and their pre-understandings. The discovery of false applications is an important goal of this concept, specifically the selective reading of the Bible that could jus-

\footnotetext{
54 Ibidem, $\$ 5$.

55 Ibidem, $\$ 6$ and $\$ 8$.

56 Ibidem, $\$ 6$.

57 Ibidem.

58 See also: Beverly Roberts Gaventa, "Interpreting the Scriptures Together: Seeking the Visible Unity of the Church", in: Journal of Ecumenical Studies 43 (3/2008), p. 309-319.
} 
tify apartheid. ${ }^{59}$ The document also presents the Church as a hermeneutic community where ecumenical hermeneutics not only interpret texts, symbols and practices, but also interpret interpreters, or in other words, it interprets the interpretative community. ${ }^{60}$

This is related to the fact that ecumenical hermeneutics, as part of theological hermeneutics, is much more than an interpretation of Scripture. The interpretation of Scripture is not even possible if we isolate the Bible from other texts. These "other" texts include the creeds of the early Church, the works of the Church Fathers, documents from the Reformation period, confessional documents, papal encyclicals and documents resulting from bilateral or multilateral ecumenical dialogues. Symbols, used in Christian art, sermons, music, worship, sacramental acts and repentance can also be considered to be the subject of ecumenical hermeneutics. All of this, not only Scripture, has been transmitted and shaped in the tradition of faith throughout the ages.

Another important point is that the role of tradition is very seriously perceived in understanding Scripture. ${ }^{61}$ This has been thematised already in a Montreal document, ${ }^{62}$ but it was not sufficiently explained how one Tradition can be embodied in particular traditions; the linguistic solution, which was based on the initials , $t^{\prime}$ and,$T^{\prime}$, did not prove functional in any other languages except English. Unlike the Montreal document, here is stated that:

(i) hermeneutics and interpretation concern both Scripture and Tradition / tradition / traditions, and that it is incorrect to separate them;

(ii) the interpretation of Scripture itself is undoubtedly conditioned by the confessional factors and

(iii) ecumenical hermeneutics is a process that involves more people from more communities who strive to access texts from their own confessional position, but at the same time to be faithful to Tradition.

Ecumenical hermeneutics thereby dissociates itself from comparative ecclesiology, ${ }^{63}$ that is, when churches interpret Scripture (creed, symbols and

\footnotetext{
59 A Treasure in Earthen Vessels, $\$ 28$.

60 Ibidem.

${ }^{61}$ Ibidem, $\$ 5$.

${ }^{62}$ William Tabernee was a member of a discussion group (Lyon, 1996) and admits that they started from a turning point that took place in Montreal in 1963. See more in: William Tabernee, "Interpreting the Scriptures Together: Seeking the Visible Unity of the Church", in: Journal of Ecumenical Studies 43 (3/2008), p. 295-308.

${ }^{63}$ On term "comparative ecclesiology" see: W. Tabernee, "Interpreting the Scriptures Together", p. 300.
} 
rituals) through the lens of their own understanding of the texts and symbols, and try to determine the extent to which the interpretations of other churches coincide with their interpretations. Following the comparative ecclesiology, if they agree, then their interpretation is good; if not, then the interpretation is automatically considered incorrect.

This approach was evident in the responses to the Lima document. Unlike comparative ecclesiology, ecumenical hermeneutics, like any other dialogue, includes accepting that the other may be right, and that his understanding can enrich or correct one's own understanding. It thus admits the possibility of metanoia and transformation as a part of authentic dialogue. Therefore, the document states that: "Any church that is unwilling to listen to the voices of other churches is at risk of failing to perceive the truth of the Spirit operating in other churches." ${ }^{64}$ Thus, ecumenical hermeneutics does not assume that one church can claim the full truth, but that each church brings something. At the same time, it acknowledges that the Church as a whole will be impoverished if the diversity and diversity of Christian perceptions of texts, symbols, practices and rituals are harmonized into singular uniformity.

Ecumenical hermeneutics in principle does not favour any particular interpretation method. Although it uses a variety of interpretative and exegetic methods, none is preferred, but quite the contrary, the multiplicity of interpretative approaches seems to be the basis for grasping the richness of texts and symbols. The aim of ecumenical hermeneutics is not to prove the superiority of one interpretation over the other, but through different interpretations to find a way to our partners in the ecumenical dialogue. ${ }^{65}$

This is achieved by distinguishing between catholicity and contextuality. ${ }^{66}$ Contextuality refers to the interpretation and proclamation of the Gospel in the life and culture of a particular community. Catholicity, on the other hand, means the fullness, integrity and totality of life in Christ, as the wholeness of the Christian community, across time and space. It is the interplay of contextuality and catholicity that unites the Church in its quest for unity, while allowing the revelation of one-sided interpretations of Scripture. The interaction of contextuality and catholicity in this ongoing dialogue characterizes the Church as a hermeneutic community that shifts the emphasis from documents and traditions, scientific methods and questions of plurality towards seeking ways to interpret together. As Pavol Bargár from

\footnotetext{
${ }^{64}$ A Treasure in Earthen Vessels, $\$ 58$.

65 "(...) meet the biblical authors as partners in ecumenical tradition". "Response to BEM by Protestant Church Federation”, in: M. Thurian, Churches Respond to BEM, vol. 6, p. 77.

${ }^{66}$ A Treasure in Earthen Vessels, $\$ 44-45$.
} 
Charles University (Prague) argues, it is exactly the model of communal and contextually-relevant readings of Scripture as are practiced by many global South Christians and churches, which helps to overcome the gap between collectivism and individualism that has over the last decades emerged in many societies. ${ }^{67}$

A Treasure in Earthen Vessels was received with both praise and criticism. Ingolf Dalferth rated the document as a step forward to modern and methodical ecumenism, but at the same time criticized it for the false idea of visible unity of the Church, which remains centred on the Church. ${ }^{68}$ This criticism brings Dalferth back to the very definition of what hermeneutics is. Although the document proposes a broader definition of hermeneutics, the problem remains that this perception of hermeneutics relies on common dictionary definitions and that the document does not give its own definition of hermeneutics. ${ }^{69}$

However, it is not actually distinguished between hermeneutics as a discipline of understanding (Kunstlehre) and the process of understanding itself. What is more, Schleiermacher's distinction between lax and strict hermeneutic practice points out that understanding does not come in by itself, but must be pursued; therefore, what comes automatically into the relationship between churches is misunderstanding.

Therefore, hermeneutics must be the theory of understanding that reflects both the circumstances of correct understanding and the reasons why understanding failed. But there is a fundamental problem with hermeneutics as "hermeneutics for unity" for Dalferth, because no hermeneutics can be used for church purposes and cannot be bound by a program of unity. ${ }^{70}$ For hermeneutics cannot be regulated because it always contains the freedom of the individual to understand in another way.

${ }^{67}$ P. Bargár, "The Reformation”, p. 87.

68 Ingolf U. Dalferth, Auf dem Weg der Ökumene, Lepzig, Evangelische Verlaganstalt 2002, p. 257.

69 This emphasizes also Ulrich H.J. Körtner, "Towards an Ecumenical Hermeneutics of Diversity: Some Remarks on the Hermeneutical Challenges of the Ecumenical Movement", in: Theology Today 68 (4/2012), p. 452. In particular, it was the consultation in Bossey (1997) that created the term "ecumenical hermeneutics", but never defined it precisely. The discussion of the adjective "ecumenical" was brief, but much was discussed about the word "hermeneutics". First, a distinction had to be made between the terms (in English) "hermeneutic" and "hermeneutics" and also between biblical and ecumenical hermeneutics. The term "ecumenical hermeneutics" seemed to be an appropriately chosen term covering the variety of methodologies used in contemporary biblical literature, and at the same time applied to the entire theological academic program, not just to Scripture. See the report of Michael Prokurat, "The Pneumatological Dimension in the Hermeneutical Task", in: P. Bouteneff, D. Heller (eds.), Interpreting Together, p. 102-110.

70 I. Dalferth, Auf dem Weg der Ökumene, p. 262. 
Ulrich Körtner, in his project of ecumenical hermeneutics as a hermeneutics of difference, draws on Dalferth's contribution, and questions the ecumenical hermeneutics that seeks unity and consensual ecumenism. ${ }^{71} \mathrm{He}$ emphasizes that if faith is not a set of rules, but contains the individual's freedom to understand differently, ecumenical hermeneutics should not be hermeneutics of unity, but hermeneutics of diversity or difference. ${ }^{72}$ According to him, hermeneutics is not a theological tool for building consensus and breaking the division between churches, because the existence or absence of consensus can be diagnosed methodologically and hermeneutically, but cannot be made. Here Körtner agrees with Dalferth.

Similarly, Körtner further points out that it is not exactly explained what is meant by the fact that texts, symbols, rituals and practices are the subject of ecumenical hermeneutics. ${ }^{73}$ This area was the subject of a consultation in Vienna in 2004, where participants based the symbol on the concept of Paul Ricoeur and Paul Tillich, and the symbol was defined as " a visible entity that both points toward and participates in a reality beyond itself." ${ }^{\prime 4}$ In addition, Körtner criticizes the very concept of the symbol, which he considers to be non-theological and non-Christian; for him the semiotic approach is crucial, which means that the symbol does not contain two, but three components. The third component is an interpreter that allows signs to function as signs.

The semiotic approach, which helps Körtner to build a critique against the document $A$ Treasure in Earthen Vessels, emphasizes that signs are not signs in themselves, but only through a relationship to the subject and context. ${ }^{75}$ Körtner's approach can be summed up by his assertion that ecumenical hermeneutics is not a tool for promoting any program of unity, but rather an art that allows us to discover and better understand the complex similarities that unite all confessions, regardless of their differences. ${ }^{76}$

${ }^{71}$ Idem, "Towards an Ecumenical Hermeneutics of Diversity: Some Remarks on the Hermeneutical Challenges of the Ecumenical Movement", in: Theology Today 68 (4/2012), p. 448-466; idem, Wohin steuert die Ökumene? Vom Konsens- zum Differenzmodell, Göttingen, Vandenhoeck \& Ruprecht 2005; idem, "Von der Konsensökumene zur Differenzökumene. Krise und Verheißung der ökumenischen Bewegung an der Schwelle zum dritten Jahrtausend", in: Kerygma und Dogma 47 (2001), p. 290-307.

72 U. Körtner, "Towards an Ecumenical Hermeneutics", p. 454. See: Thomas FornetPonse, "Komplementarität und differenzierter Konsens: Perspektiven einer ökumenischen Hermeneutik aus katholischer Sicht", in: Catholica 66 (2012), p. 254-272.

73 U. Körtner, "Towards an Ecumenical Hermeneutics”, p. 458.

74 Ibidem, p. 458.

75 Ibidem, p. 463.

76 Ibidem, p. 466. 


\section{Zdenko Š Širka}

\section{Recent developments}

A Treasure in Earthen Vessels is not the end stop, it is a point where it is necessary to further continue, but as Pablo Andiñach points out, ${ }^{77}$ it is not possible to reach consensus within a few years. The development of ecumenical hermeneutics therefore continued, with consultations in Strasbourg (2002) and Vienna (2004).

In Strasbourg ${ }^{78}$ it was shown, that the clash between church tradition and the social context is not as sharp as was expected. It was stated that different contexts or perspectives exist from which it is possible to read and interpret ecumenical documents, Scripture and Christian denominations. These are the liturgy as the focus of interpretation, the life of the Church, the canon of Scripture, the individual doctrines of specific traditions, the teaching of the Ecumenical Committees and the Councils, and the social context and its challenges. ${ }^{79}$ This list is obviously not complete, ${ }^{80}$ but the participants concluded that heritage across the entire church tradition and throughout the ages is now shared, and provides a common framework in which Scripture is read.

Diversity is therefore not an enemy of unity, but provides a starting point from which we can begin to seek common perspectives. Susan Durber, the moderator of the debate, adds that even if the Church was united, it would still not provide a clear reading. The problem does not lie in the diversity of the Church, but it lies in the reading itself, as no reading can ever be objective. ${ }^{81}$ Durber uses an example from Jonathan Magonet, who asks what a donkey would search for when reading the Bible, if he could read it. The answer is: stories about donkeys. At the same time, the donkey will be tempted to skip and ignore other parts. We can recognize that donkeys have the right to read the Bible as they wish, but their Bible reading will be specific and special, reflecting their own perspective.

But a good reader must also be led to stories that are not about him, or perhaps even contradict his own experience or deny it. This includes the

\footnotetext{
77 Pablo R. Andiñach, "Interpreting Our Faith: The Ecumenical Journey and Its Consequences", in: Thomas F. Best (ed.), Faith and Order at the Crossroads: Kuala Lumpur 2004, The Plenary Commission Meeting, Geneva, WCC Publications 2005, p. 270.

78 Report in: T. F. Best (ed.), Faith and Order, p. 295.

79 See also report from the ecumenical meeting in Hamburg (2006): Sören Asmus, Stefan Höschele, "Ökumenische Hermeneutik zwischen Kontexualität und Konfessionalität”, in: Ökumenische Rundschau 56 (3/2007), p. 393-400.

80 P. Andiñach, "Interpreting Our Faith”, p. 271.

81 Susan Durber, "On Ecumenical Hermeneutics", in: T. F. Best (ed.), Faith and Order, p. 279.
} 
question of requirements to ascertain whether this or that interpretation is correct. A negative criterion was underlined as important, this means the situation where the interpretation of Scripture cannot be valid if it results in degrading the lives of human beings, lowering their dignity and damaging their culture. The Church should always be suspicious of those who claim to have the power to discern the correct interpretation.

This consultation underlined that besides the confessional identities, the strong influence of the social context is evident as well. Thus, in the application of ecumenical hermeneutics, it is not possible to discover the meaning of Scripture in isolation, but only by combining various critical methods that allow everyone to verify the interpretation of their own traditions and gain healthy criticism from brothers and sisters from other traditions.

The consultation in Vienna $(2004)^{82}$ dealt with the issue of symbol. It was first explained what symbol, ritual, and practices are, then participants focused on how symbols can be the building blocks of our identity. It was a reaction to the criticism of Körtner and Dalferth. The symbol is considered to be a mark pointing out of itself to the presence of God, such as bread and wine, Scripture, water of baptism, the Cross and other Christian symbols.

Certain pious practices, liturgical rites and some texts have also gained symbolic value, namely confession, a prayer and a liturgical year. Ritual is understood to be an institutional liturgical event that has a specific meaning for a particular church, such as baptism, communion, and prayer. Practices are defined as institutional or personal actions expressing the Christian faith in various forms. Believers experience symbols not only as part of their ecclesiastical identity, but also as a component of personal identity.

It was concluded that baptism and communion are considered almost universal symbols of the Christian faith, but a different understanding of their meaning and nature still persists. It is precisely these ceremonies that on one hand unite us across cultures, and on the other divide us as we interpret them. The need for certain rules was noted, because not every bread is the bread of communion, not all water is the water of baptism, and some pictures are not icons. This again raised the question of authority: who has the power to decide what should be considered sacred, to decide who can administer sacred testimonies, or to allow a person to participate in the ceremony, etc.? There was agreement on some basic criteria, but at the same time, the participants refused to agree on a method or authority that would legitimize a method, because it would no longer be an ecumenical hermeneutic, but a uniformly unifying interpretation. If we return to the Canberra

82 A new format was tried here: presentations were always in pairs, from the same confession, but from different contexts. 
1991 conference and Chung Hyun Kyung from the beginning of this article, we see how the question about the legitimizing of the contextual theology returns. ${ }^{83}$ There is no space in this short paper to further explore the contexts in the global South (Africa, Asia, Latin America), but let me mention at least that the clash between the hermeneutics of tradition based on the tradition of the apostolic faith, and the framework of contextual theology lies in the so called transformations of tradition. While in relations between the churches common awareness of the importance of tradition is ever growing and has led to convergences, its unavoidable transformation in our postmodern and post-secular society has raised new conflicts and led to divergences. This transformation of tradition is given by its double character. On one side tradition is inclusive, open and universal, katholikos, converging on one God, one faith, one church; on the other side tradition is exclusive, closed, interpreted and applied in a concrete time and place, receiving tangible form and shape. But none of these is automatically authentic, various contextual readings may justify abuse, non-contextual attitudes may bring violations. I assume that the authentic theology of tradition will have to preserve the hermeneutical circle between inclusive and exclusive approaches, which is not attainable without keeping in mind its limits that lead to its transformations. A hermeneutical circle is understood when a whole is established by reference to the individual parts and understanding of individual parts is established by reference to the whole, they can be understood only by reference to one another. In the terminology of Treasure in Earthen Vessels, it is the interaction between the contextuality and catholicity.

The results of both consultations were presented at the Faith and Order plenary commission of the World Council of Churches assembled in Kuala Lumpur, Malaysia in 2004. However, the discussions took an unexpected direction which was initiated by Hilarion Alfeyev in his contribution. ${ }^{84}$

Alfeyev is convinced that contemporary ecumenical hermeneutics is too theoretical and separated from real life. He therefore suggested that a new course should be explored at the Ninth Assembly of the World Council of Churches in Porto Alegre, Brazil (2006). Alfeyev believed that a study about the meaning of patristics and Church Fathers was needed in hermeneutics. He named various arguments, such as that the knowledge of the Fathers would provide an opportunity to better understand the tradition

\footnotetext{
83 On the topic see the standard textbook: Steven B. Bevans, Models of Contextual Theology, Maryknoll, NY, Orbis Books 2002.

${ }^{84}$ Hilarion Alfeyev, "Proposals for the Future Direction of the Hermeneutics Study", in: T.

F. Best (ed.), Faith and Order, p. 283-285.
} 
of the Church before the schism, and will allow Christians to better get to know themselves.

Furthermore, according to Alfeyev, the Fathers will never lose their importance, because they dealt with questions and answers that are crucial to the presence and future of Christianity. Finally, the Church Fathers are a good source of material about the meaning of prayer. ${ }^{85}$ Alfeyev referred to a document from Bristol (1967), which recommended using patristic texts in ecumenical documents, ${ }^{86}$ but this never happened.

Alfeyev's plea was fulfilled in September 2008 when 24 participants gathered at Westminster College in Cambridge to join the first of a series of consultations called "Tradition and traditions". This has finally given special attention to the teachers and witnesses of the Early Church and explored the possibility of rediscovering them as a source of stimuli that can assist on the way to unity. Therefore, the participants created a document called Teachers and Witnesses of the Early Church: A Common Source of Authority, Variously Received? ${ }^{87}$ The moderator of this group was Susan Durber, who rated it as high quality, not only academically but also spiritually. ${ }^{88}$

At the plenary meeting of the Commission in Crete in $2009^{89}$ the debate continued in the discussion group "Tradition and traditions". The group explored how individual patristic texts can be portrayed as a source of authority in the Church in general and in their local ecclesial contexts. A further meeting on the subject was scheduled for 2011, but did not happen.

Cyril Hovorun (instead of Alfeyev) spoke there ${ }^{90}$ and repeated the appeal of rediscovering patristic sources that had been forgotten until 2004.

85 Konrad Raiser spoke similarly at his public lecture in Thessaloniki in 2003 titled "The Importance of the Orthodox Contribution to the WCC."

${ }^{86}$ New Directions in Faith and Order, Bristol 1967: Reports, Minutes, Geneva, WCC Publications 1968, p. 43.

87 See: https:/www.oikoumene.org/en/resources/documents/commissions/faith-and-order /x-other-documents-from-conferences-and-meetings/cambridge-report-on-tradition-andtraditions, viewed on October 21, 2019.

88 S. Durber, Tradition and traditions, 10 October 2009, available online https://www.oikoumene.org/en/resources/documents/commissions/faith-and-order/x-other-documents-fromconferences-and-meetings/plenary-commission-meeting-crete-2009/tradition-and-traditions-rev-dr-susan-durber, viewed on October 21, 2019.

89 It was attended by 120 members of the Committee for Faith and Order and 37 guests. The report is available online: https://www.oikoumene.org/en/resources/documents/commissions/faith-and-order/x-other-documents-from-conferences-and-meetings/plenary-commission-meeting-crete-2009/report-of-the-2009-plenary-commission-meeting, viewed on October 21, 2019.

90 Cyril Hovorun, "Teachers and Witnesses of the Church: Space for Ecumenical Convergence”, 10 zárí 2009, https://www.oikoumene.org/en/resources/documents/commissions/faith-and-order/x-other-documents-from-conferences-and-meetings/plenary-com- 


\section{Zdenko Š Širka}

He commented positively on the consultation in Cambridge (2008) and stressed that we should not approach the Fathers with specific expectations, but rather listen to what they are telling us. The ecumenical community should be aware of the connection between early teachers and Scripture and see in it the possibilities for the success of ecumenical dialogue. ${ }^{91} \mathrm{He}$ made two proposals: first, to initiate a study that would show a connection between Church Fathers and Scripture; and second. to establish the practice that every ecumenical document should be supported not only by references to Scripture, but also by references to the Church Fathers.

These proposals are currently under development.

\section{Further paths}

What influenced the development of ecumenical hermeneutics, especially the document $A$ Treasure in Earthen Vessels? Where did these breakthrough ideas come from? I believe that the emergence of ecumenical hermeneutics is connected with changes in philosophical hermeneutics in the $20^{\text {th }}$ century as well as its representatives, who influenced theological ideas and influenced ecclesial views and practices. It is precisely a result of this development that the concept of hermeneutics and its questions have become a common place not only for biblical and Christian theology, but above all for the ecumenical movement.

However, this influence is not direct, cannot be proven and the notes of ecumenical documents do not contain references to hermeneutic literature. Just as the classical hermeneutical literature ignored the development of ecumenical hermeneutics, in the ecumenical movement no one explicitly reflected the influence of secular hermeneutics. Still, the selection of ecumenical topics such as conversation, tradition, context, reception, indirectly points to the hermeneutics of Hans-Georg Gadamer, which can be summarized by the term ecumenical conversation. ${ }^{92}$

Take as an example his essay "Europa and Oikoumene" (1993), where he writes "we must learn to think ecumenically", ${ }^{93}$ and he writes there about

mission-meeting-crete-2009/tradition-and-traditions-archimandrite-cyril-hovorun, viewed on October 21, 2019.

${ }^{11}$ One of the events that followed this challenge was the conference organized by the St Andrews Biblical Theological Institute and the Monastery in Bose (Italy) in October 2013 on "Ecumenical Theology and Hermeneutics in the Post-Modern Age".

92 On this see: Zdenko Širka, Transcendence and Understanding: Gadamer and Modern Orthodox

Hermeneutics in Dialogue, Eugene, OR, Pickwick 2020, p. 55-80.

93 Hans-Georg Gadamer, Gesammelte Werke 10 Hermeneutik im Rückblick, Tübingen, Mohr Siebeck 1995, p. 271. 
speech, conversation, the ability to listen, to respect what others share, the significance of ongoing questions, and the realization that truth is more than a cognitive matter - all these are contributions to ecumenical hermeneutics. ${ }^{94}$ Behind Gadamer's reflection about the nature of understanding lies an analogy between understanding and genuine conversation, where the reader (interpreter) not only recognises the otherness of the other (as in therapeutic conversation), but also recognises the claim over partners in the conversation and listens to what it has to say to them. In other words, when I listen, I do not try to understand the other and so to gain dominance over him, but I try to listen to what he has to say and to learn from him. Gadamer's argument is that understanding is always a part of dialogue, or in other words, that understanding is dialogical. Words such as 'dialogue' and 'conversation' are not metaphors and they lie at the centre of Gadamer's description of understanding, "conversation that we ourselves are." 95 A dialogue has many characteristics, one of them is incompleteness, since the dialogue is never planned or complete, and we never conduct or lead dialogue, but we fall into it. ${ }^{96}$ The prefix $\delta i \alpha ́$ (common for dia-lectics and dia-logue) is very important, because it points to a certain incompleteness that emerges. Dialogue moves in ways that cannot be predicted and the participants are usually transformed by it. We might try to achieve an understanding of an object, but what always appears in the conversation is the "logos, neither mine nor yours and hence transcends the interlocutor's subjective opinions that even the person leading the conversation knows that he does not know." ${ }^{97}$ Dialogue as a 'fusion' means that the encounter of horizons is not the elimination of the other, but describes a mutual interaction and accommodation to the other. Fusion does not abolish or overshadow the other, let us say the past, but takes up the horizons and expands on them.

At the heart of ecumenical and hermeneutic awareness is therefore, in Gadamerian sense, a recognition of diversity, willingness to talk and meet although understanding or consensus does not seem possible, awareness of one's own prejudice or pre-understanding, deep awareness of one's own posi-

94 On this issue see also: Christoff Pauw, Dirk J. Smit, "The Conversation That We Are - Reflections on Ecumenical Hermeneutics", in: South African Journal of Philosophy 21 (2/2002), p. 19-39, 30-34. An attempt to connect work of Gadamer with theology has already been published on the pages of this journal, see: Z. Širka, "Gadamer's Concept of Aesthetic Experience as a Possibility for the Orthodox Biblical Theology", in: Review of Ecumenical Studies 6 (3/2014), p. 378-407.

95 H.- G. Gadamer, Wahrheit und Methode, Tübingen, Mohr Siebeck 1990, p. 382: “von dem Gespräch aus, das wir sind."

96 See: Ibidem, p. 387.

97 Ibidem, p. 373-374. 
tion in history, and awareness of the existence of something greater than the individual in time, the decisive role of discernment, and the confidence that we are known before we get to know. ${ }^{98}$

The goal of ecumenical hermeneutics should not be to decide which one is right, nor even to seek common features in order to create new ecumenical hermeneutics. Ecumenical hermeneutics is actually more about gathering around a table with an open Bible where we can listen to others and learn from each other how to become better readers than we already are. In other words, it does not seek commonality, but understanding and mutual recognition. Pablo Andiñach, for whom hermeneutics is about respect to others, concludes his speech in Kuala Lumpur with words, now already famous: "I believe that, in the ecumenical journey towards a shared hermeneutics, we should aspire first to understand, then to respect, then to appreciate and finally to love the interpretations, rites, symbols and practices that are dear to the hearts of our Christian brothers and sisters." ${ }^{99}$

98 In his ecumenical hermeneutics, Anton Houtepen considers Ricoeur's seconde naivité as a starting point, because he does not perceive meaning as a kind of objective historical data, as was the case with Betti and Dilthey, or as a result of our interpretation as it was with Gadamer and Derrida. He feels positively with Gadamer that he abolished the archaeological effort of Romanticism to enter the world of the author and came up with the theory of merging horizons between the text and the current situation. He acknowledges that this concept has greatly influenced theology and especially ecumenism. But Houtepen follows a skeptical interpretation of Heinz-Günther Stobbe (Hermeneutik - ein Ökumenisches Problem: Eine Kritik der katholischen Gadamer-Rezeption, Gütersloh, Gütersloher Verlagshaus Gerd Mohn,1981), according to which Gadamer does not know the goal of understanding and does not seek better understanding. Therefore, Houtepen does not consider it useful in ecumenical hermeneutics, but turns to Ricoeur, who emphasizes that truth and meaning can only be grasped through symbols. See the article from Aukje Westra (Aukje Westra, "Ecumenical Hermeneutics: Criteria for Truth and Justice", in: Kurt Schori et al. (eds.), The Living Tradition: Towards an Ecumenical Hermeneutics of the Christian Tradition, Utrecht, Interuniversitair Instituut voor Missiologie en Oecumenica, 1995, p. 71-85), which compares the hermeneutic models of Houtepen and Edward Schillebeeckx and shows that the two models correspond to each other.

99 P. Andiñach, "Interpreting Our Faith”, p. 277, repeats it also; H. Durber, “On Ecumenical Hermeneutics", p. 282. See also: "The challenge to move on from mutual understanding to mutual recognition is now before the churches in the search for visible unity." in: A Treasure in Earthen Vessels, $\$ 34$. 